\title{
Use of feces to attract insects by a Glittering-bellied Emerald, Chlorostilbon lucidus (Shaw, 1812) (Apodiformes: Trochilidae)
}

\author{
Fábio André Facco Jacomassa \\ Programa de Pós-Graduação em Zoologia, Departamento de Zoologia \\ Instituto de Biociências, Universidade Estadual Paulista \\ Avenida 24A, 1515, Vila Bela Vista, CEP 13506-900, Rio Claro - SP, Brazil \\ fabioafj@gmail.com
}

Submetido em 05/03/2014 Aceito para publicação em 28/05/2014

\section{Resumo}

Uso de fezes para atrair insetos por um besourinho-de-bico-vermelho, Chlorostilbon lucidus (Apodiformes: Trochilidae). Este estudo descreve a ocorrência de uma fêmea de besourinho-de-bico-vermelho Chlorostilbon lucidus, usando suas fezes para atrair insetos para perto do seu ninho para predá-los. Este é o primeiro registro de um beija-flor usando fezes para atrair insetos.

Palavras-chave: Comportamento; Ninho; Predador; Presa

\section{Abstract}

This study describes the occurrence of a female Glittering-bellied Emerald, Chlorostilbon lucidus, using feces to attract insects to the nesting site for predation. This is the first report of a hummingbird using feces to attract insects.

Key words: Behavior; Nest; Predator; Prey

Some animals use feces, either their own or that of other animals, to attract insects in order to prey upon them (LEVEY et al., 2004, SMITH; CONWAY, 2007). Insects may be attracted to feces for several reasons, including for egg deposition, as a food source, or when confuse by exhaled sex pheromones (HALFFTER; MATTHEWS, 1966; OLIVEIRA et al., 1996). For instance, it is known that bird feces may attract Dipteran females (Culicidae and Psychodidae) for oviposition (ELNAIEM; WARD, 1992; COOPERBAND et al., 2008). Here I report an incubating Glittering-bellied Emerald preying upon insects attracted to its feces near its nest. As far as I know, this is the first report of a hummingbird using feces to attract insect prey.

Hummingbirds are exclusively Neotropical, and their diet consists of nectar and insects (SCHUBART et al., 1965; STILES, 1981; SICK, 2001). The Glitteringbellied Emerald, Chlorostilbon lucidus (Shaw, 1812), is a widespread species, common in a broad range of semi-open habitats, including gardens and parks in north-eastern Argentina, Paraguay, Uruguay, in southern, southeastern, midwestern, and northeastern Brazil, in eastern and central Bolivia, and Peru (SICK, 2001; BIRDLIFE INTERNATIONAL, 2012). 
In October $27^{\text {th }}$ 2011, I observed a Glittering-bellied Emerald nest with an egg, approximately $7 \mathrm{~m}$ above the ground on a branch of a Creeping Fig (Ficus pumila L., Moraceae) (Figure 1a) adhered to a building at the State University of São Paulo (UNESP) in Rio Claro, SP, Brazil (4732'40”'W, $22^{\circ} 23^{\prime} 47^{\prime}$ 'S). The incubating female was depositing feces with her beak on the wall of the building next to the nest (within $20 \mathrm{~cm}$ ) (Figure 1b). The next day, I observed insects flying over the feces (Figure 1c). During 50 hours of focal observations in November 2011, I observed the deposition of feces on the wall twice. On November $27^{\text {th }}$ at $15: 12$ p.m. and November $30^{\text {th }}$ at 16:00 p.m., I observed the female preying on insects (Diptera, Psychodidae) that were flying over the feces (Figure 1d).
Animals sometimes use tools to attract prey (BENTLEY-CONDIT; SMITH, 2010; DINETS et al., 2013). As noted by Smith and Conway (2007) and Levey et al. (2004), the Burrowing Owl (Athene cunicularia) uses feces to attract its prey (especially Coleoptera: Scarabaeidae), and it is known that bird feces attract Dipteran females (Culicidae and Psychodidae) for oviposition (ELNAIEM; WARD, 1992, COOPERBAND et al., 2008). Reports of similar behaviors are scarce, and my observations support this scenario.

During incubation, bird's eggs, hatchlings and parents are more subject to predation. Therefore, females tend to accumulate fat, which allows them to spend the maximum amount of time incubating their

FIGURES 1: Female Glittering-bellied Emerald on the nest (a), depositing feces on the wall next to the nest (b), insects flying near the feces (c), and the female preying upon the flying insects (d). Drawings based on actual observations.

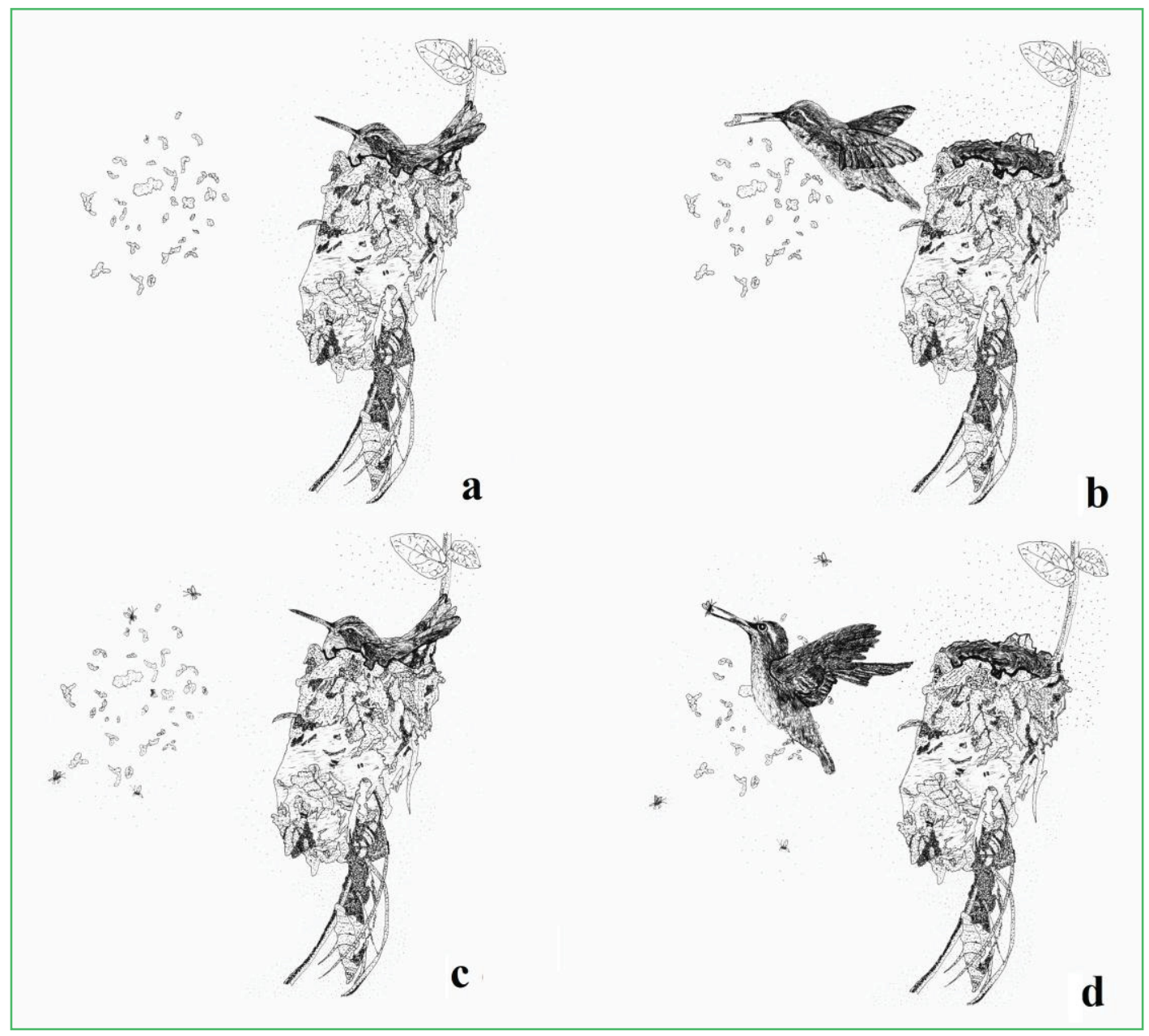


eggs (SLAGSVOLD; DALE, 1996). They may also use feces to mask the scent of chicks (LEVEY et al., 2004). Female hummingbirds, while incubating their eggs, busy themselves picking tiny insects near the nest within their reach, and their efforts to clean the nest are minimal (SICK, 2001). These behaviors are important for rapid incubation and protection of the nest, because they minimize the need for spending time away from the nest.

Advantages for the female hummingbird of attracting prey with her feces seem to be protection of the nest by her proximity to it, reduced energy expenditure due to foraging, and increased incubation time. In addition, the feces may also disguise the scent of her nestlings, rendering them less vulnerable to predation.

This is the first report of a hummingbird using feces to attract insects. The female must only travel a short distance to get food, thus reducing her energy expenditure, resulting in increased the incubation time and nest protection, which in turn enhances reproductive success.

\section{Acknowledgements}

I thank UNESP, Campus of Rio Claro, Dr. Marco A. Pizo, Dr. César Cestari, Dra. Sulene N. Shima and Msc. Adolfo S. Melo for their contributions to this manuscript, and Capes for providing a scholarship. I would also like to thank Jaime R. Somera and Dr. Fábio R. A. Hernandes for instruction in scientific illustration, and Dr. Edilberto Giannotti for insect identification.

\section{References}

BENTLEY-CONDIT, V. K.; SMITH. E. O. Animal tool use: current definitions and an updated comprehensive catalog. Behaviour, Leiden, v. 147, n. 2, p. 185-232, 2010.

BIRDLIFE INTERNATIONAL. Chlorostilbon lucidus. In: IUCN 2013. Red list of threatened species. Version 2013.2. 2012. Available in: $<\mathrm{http}: / /$ www.iucnredlist.org $>$. Accessed on: 27 November 2013.

COOPERBAND, M. F.; McELFRESH, J. S.; MiLlaR J. G.; CARDÉ, R. T. Attraction of female Culex quinquefasciatus Say (Diptera: Culicidae) to odors from chicken feces. Journal of Insect Physiology, Oxford, v. 54, n. 7, p. 1184-1192, 2008.

DINETS, V.; BRUEGGEN, J. C.; BRUEGGEN, J. D. Crocodiles use tools for hunting. Ethology, Ecology \& Evolution, Firenze, v. 26, 2013 (in press).

ELNAIEM, D. A.; WARD, R. D. Oviposition attractants and stimulants for the sandfly Lutzonmyia longipalpis (Diptera: Psychodidae). Journal of Medical Entomology, Lanham, v. 29, n. 1, p. $5-12,1992$.

HALFFTER, G.; MATTHEWS, E. G. The natural history of dung beetles of the subfamily Scarabaeinae (Coleoptera: Scarabaeidae). Folia Entomologica Mexicana, Xalapa, v. 12/14, p. 1-312, 1966.

LEVEY, D. J.; DUNCAN, R. S.; LEVINS, C. S. Use of dung as a tool by burrowing owls. Nature, London, v. 431, n. 9, p. 39, 2004. OLIVEIRA, G. P.; SILVA, A. L.; MENDES, J.; TAVARES, L. N. J. Insetos associados a fezes de bovinos na região de São Carlos, São Paulo. Ciência Agronômica, Fortaleza, v. 27, n. 1/2, p. 39-47, 1996.

SCHUBART, O.; AGUIRRE, A. C.; SICK, H. Contribuição para o conhecimento da alimentação das aves brasileiras. Arquivos de Zoologia, São Paulo, n. 12, p. 95-249, 1965.

SICK, H. Ornitologia brasileira. Rio de Janeiro: Editora Nova Fronteira, 2001.912 p.

SLAGSVOLD, T.; DALE, S. Disappearance of female Pied flycatcher in relation to breeding stage and experimentally induced molt. Ecology, Ithaca, v. 77, n. 2, p. 461-471, 1996.

SMITH, M. D.; CONWAY, C. J. Use of mammal manure by nesting burrowing owls: a test of four functional hypotheses. Animal Behaviour, Leiden, v. 73, n. 1, p. 65-73, 2007.

STILES, F. G. Geographical aspects of bird-flower coevolution, with particular reference to Central America. Annals of the Missouri Botanical Garden, Saint Louis, v. 68, n. 2, p. 323-351, 1981. 